\title{
Role of Teacher Training Institute in 21st Century
}

\author{
Yashumati Jamwal \\ Department /Country Education /India
}

\begin{abstract}
This paper presentation is related with Teacher's Training Institutes .As this is a noble profession changing scenario has brought change in this field.Gone were the days when stress was laid upon academic development of the child.Now-a-days more emphasis is being laid down on overall development of the learner .Who is responsible for brining modification in the behavior of the learner? Answer is simple'Teacher'. Apart numerous other factors are responsible for bringing change. If a trainer is capable enough to produce an effective, honest and co memorable teacher means something has been initiated in this direction. So the job of the teacher is to bring out the hidden gem like potentialities in pupils and to make all possible efforts to ensure that the tender plants i.e. students don't waste their energies in unattractive and uncongenial environment. Teaching is not just limited to classroom a teacher trainer has to train teachers who can really do wonders during academic development of their career. Is Only teacher responsible of making teachers like Dr Radhakrishnan and many others. A trainer needs lot other things and situations for setting examples apart from his will .The CTET conducted in 2012 has send an awakening call among teaching fraternity has placed a challenge before the training institutions and question about quality of poor production which will definitely bring disastrous results for the nation. Many commissions have been setup to improve education system in India .Higher education acts as fertile ground for experimenting new ideas and techniques and inculcating values .Certain factors are behind degrading standards of teacher training institutions. Here introspection as teacher educator and responsibility of teacher training institution needs to be recognized and identified.This research paper contains suggestions for brining improvement in B.ed syllabus and education of teacher training institutions.
\end{abstract}

Keywords: Agencies, curriculum programme, CTET,Students, teacher educator, Training institutions.

\section{Introduction}

"For many a gem of purest ray serene.

The dark unfathomed caves of the ocean bear.

Full many a flower is borne to flourish unseen.

And waste its sweetness in the desert air."

The job of the teacher is to bring out the hidden gem like potentialities in pupils and to make all possible efforts to ensure that the tender plants (tender pupils)do not waste their sweet fragrance (innocent smiles) in wilderness (in unattractive and uncongenial environment).Thus a teacher needs to understand the basic principles of educational psychology so that optimum development of his pupils takes place for which proper training is required.

\section{Significance Of Training}

The field of education has been benefited greatly from the ever increasing Knowledge of the characteristics of the growing child .schools need to design and organize their programme in keeping with the levels of readiness of children .seeking an Understanding of the individual child in the school mutually by parents and teachers is Important for his development .As a result of the current recognition that the individual child brings all his special attributes ,talents, attitudes, values ,skills ,competencies with him into the classroom ,a definite shift towards individuality is taking place in the curriculum.Educator, Home scientists and nutritionists have learned that the child and Subject -matter can't be separated from each other in the classroom. A good school Programme is more than a series of courses; it is based on a sound knowledge of the nature of child growth in general and on a thorough understanding of each Individual in particular . The following statement of abindranath Tagore is worth quoting here: A teacher can never truly reach unless he is still larning himself. A lamp can never light another lamp unless it continues to burn its own flame .The teacher who has come to the end of his subject, who has no living traffic with his knowledge, but merely repeats his lesson to his students, can only load their minds .He can't quicken them .Truth not only must inform ,but also must inspire .If the inspiration dies out and the information only accumulates then truth Loses its infinity. The greater part of our 
learning the schools has been a waste because for most of our teachers, their subjects are like dead specimens of once living things, with which they have a learned acquaintance but no communication of life and love.

So, the role of a teacher is not just limited to classroom teaching; he has to perform a very Significant role in the community, of which he is a member .As an academic and intellectual member of the community, he cannot remain indifferent to what goes on in the social Environment around him .Education is a social system which goes on changing along with changes taking place in the society. The role of teachers also changes in order to cope with the changes in the society and education .This justifies the need ,not only of pre-service training ,but also of in - Service training of teacher's. When the $10+2+3$ pattern of school and college education was being implemented during early 1970's new demands were thrown on teachers and consequently , on teacher education institutions. The new structure of education brought about drastic changes in the existing system by introducing the concept of vocationalization, work experience, diversification and general education up to class Xth.These,and similar other changes ,threw new challenges before teachers and teacher training institutions.

\section{Need To Revise Teacher Education Programme}

Consequently, there was a strong move to revise teacher education programme and to launch large scale -in-service teacher education courses to help teachers adjust to the new situations effectively. Similarly the NPE-1986 brought new ideas and fresh proposals to improve the quality of education at all levels with the introduction of concepts like operation blackboard ,minimum levels of learning ,Micro-planning, Decentralized management and modernization of teaching learning process. The Implementation of these ideas required a large scale orientation of teachers and a drastic change in pre-service teacher education programmes. This shows that every bit of change in school Education has its implication for teacher education .The kind of teacher training imparted earlier, say 20 years ago, is no more relevant to the current educational scenario. Teacher training, therefore, is not a one-time affair; it is continuous process in a teacher's life.

From the organizational point of view, there are mainly three types of agencies

in India that carry out programme of teacher education:

(1) Universities, which impart pre-service and in-service training through their departments of teacher education and affiliated teacher training colleges.

(2) State Governments, which have created state level training facilities in the form of state Institutes of education (SIEs) and state councils of educational research and training (SCERT) and

(3) Autonomous bodies like National Council of Educational Research and Training (NCERT) and National Institute of Educational Planning and Administration (NIEPA)

which conduct in-service and pre-service training programme at national level.

So, there are mainly three types of teachers training institutions for imparting Training to teachers of Elementary, Secondary and Tertiary levels of education respectively .For elementary stage, a comprehensive training , generally of two years duration, is organized, which leads to the award of a diploma or a certificate in teacher Education and candidates are eligible for appointment as teachers in primary Schools. The minimum qualification for admission to these courses is high school or Matriculation. For the secondary school stage, training programme are offered by the University departments of education or by colleges of education, which lead to the Award of B.ed degree. The B.ed degree holders considered eligible for appointment as Teachers in secondary schools and minimum qualification for admission to these programme is graduation from the recognized Indian or foreign university.

Training for teachers in higher education is relatively a new Phenomenon. In pursuance of the proposals of the NPE-1986, the government of India has established 48 Academic staff colleges (ASCs), which impart in -service training to Teachers in higher education .At present, 51 of such ASCs are functioning .These Institutions are fully financed by the UGC and are supposed to conduct orientation Courses for newly recruited teachers and refresher courses for existing ones .It is, therefore, evident that in India teacher education programmes are being organized at all levels of educational ladder.

Education is a core sector for achieving the objective of Employment, human resource development and brining about much needed change in Social environment, leading to overall progress through efficient use of resources. An Appropriate education system cultivates knowledge, skill, positive attitude, awareness and sense of responsibility towards rights and duties and imparts inner strength to face Oppression, humiliation and inequality.

A new national curriculum framework for teacher education was released and published in 19 march, 2010,putting more focus on field experience and re-orienting teacher's to enable children to learn through activities .putting behind the rote teaching method, the new framework,developed by national council for teacher Education (NCTE), gives importance on inclusive education ,perspective for equitable and sustainable 
development, gender perspectives and ICT in schooling and e- Learning .the framework was released by human resource development minister Kapil Sibal in New Delhi.

"The framework aims at training the teachers in such a manner that they will allow the child discover the world and learn through activity."

This framework is an outcome of an exercise undertaken by NCTE towards Improving the quality of teacher education .It has been prepared keeping in view the National curriculum framework, 2005 and the right of children to free and compulsory Education act, 2009.

The focus of this framework is towards preparing professional and humane Teachers who become reflective practitioners of educational thought and practice. The new curriculum says that teachers must engage with theory along with field experiences .It says a teacher should undergo field experiences focus days a week for a minimum period of 12-20 weeks.

The NCTE will now prepare a curriculum based on framework. A memorandum of understanding has been signed between the national Assessment and accreditation council and commonwealth of learning ( COL) to Develop modules and quality indicators in the area of teacher training.Announcing this at a press meet in Saturday V.S Prasadm Director of NAAC said worldwide practices in the area of teacher training will be studied and standards would be set accordingly. In India, to speak about the work of COL, assistant director general if COL John Daniel said that work had started with the UGC to set up learning object repositories (LOR).

In an alarming indictment of the quality of training given to prospective school teachers, more than 99\% aspirants failed to clear the central eligibility test (CTET) 2012.Theresults of the competency test conducted by the central Board of secondary education (CBSE), declared on Dec, 27, 2012, showed that less than $1 \%$ of the 7.95 lakh who appeared managed to clear exam.

In fact, since the exam was introduced in 2011 , the pass $\%$ has been consistently declining .Educationist described the situation as alarming and "a wake up call for the quality of B.ed degrees being granted in the country."TheCTET was introducing in 2011 by the union HRD ministry to prove the quality of Teaching in schools after enactment of the right to education act .CTET certification has been made mandatory to become a teacher for classes' 1-viii in any central Govt school, while CBSE affiliated schools can either recruit teachers based on CTET or the respective test conducted by states.

The Delhi Govt too has decided to adopt CTET for recruitment of teachers for Govt run and aided schools .All CTET applicants need to be B.ed graduates.

About 9.40 lakh aspirants registered for the test conducted in Nov 2012. Some 7.96 lakh appeared for the test, of which 4.849 managed to clear either Paper-1 or II or both .Clearing paper I is mandatory for those wishing to teach classes VI TO VII.Aspirants who wish to get certified for classes I-VIII need to clear both the papers.

The CTET was conducted by the CBSE for the first time in June 2011. The aggregate results of the CTET 2011 conducted by CBSE in June.

Paper-I (classes I-V) Paper -II (classes VI-VIII)

category

Appeared

255,480

100,837

$\mathbf{3 0 , 4 3 5}$

213,001
$254,612 \quad 29,931 \quad 12 \%$

$92,996 \quad 2,383 \quad 3 \%$

$21,812 \quad 389 \quad 2 \%$

$199,069 \quad 10,468 \quad 5 \%$ 
Change has become the order of the day; education today has to keep itself ready for such a change. This puts a whole lot of responsibility on the shoulder of a teacher educator and Institutes imparting education .Need and importance of teacher education in higher Education was evident as a teacher had to perform multiple activities besides these that were intrinsic to teaching and learning.

Teaching, evaluating, communicating, guiding and Counselling, organising CCA, participating in community programmes, diagnosis and remedying problems of students are only some of the main activities .All these need excellence in academic and professional preparation of teachers.

Higher education may act as a fertile ground for experimenting new ideas and techniques and inculcating values .Investments in higher Education was an investment for future .It could no longer be viewed merely as a welfare activity. It had the power to make India free from poverty, unemployment and fit to co-exist with G8 Nations.

Education and training of teacher educators has to focus its attention on the new role of teacher educators on the problems which reflect the emerging global trends in education and the overall needs and aspirations of the people in India .It has also to deal with specific problems confronting teacher education institutions and to make teacher education more responsible and responsive .It has to encourage teacher educator's continuing professional growth.

\section{Role Of Teacher Training Institutions}

The rational behind the education and professional Training of teacher educators lie in providing qualitative instruction through well- designed programmes of professional education. The following questions are relevant for designing a programme for education of teacher educators. The question is what Exactly should the education of teacher educator's aim at? Based upon the raised above, the following objectives can be comprehensively identified for the Programmes of prepration of teacher educators.

- To develop competencies and skills needed for prepration of teachers and Educators.

- To enable them to organize competency based and commitment oriented Professional programmes.

- To enable them to appreciate and adopt emerging communication technology and Innovative practices in Indian context.

The result of CTET has revealed drastic consequences which nation can face in upcoming years .Only $1 \%$ pass $\%$ is an alarming for training institutions. It has put a question mark about the quality of education being imparted by Educational institutions. Curriculum designers have failed to make 'teachers'. Need is to explore where the problem is lying?

Following are certain apparent issues related with teacher training institutions:

- Curriculum is defective as more emphasis is being laid on theory and less on Teaching practice.

- Subject like philosophy should be replaced with educational technology As Curriculum is always need based and demand of the hour is we need more Technocrats.

It has been rightly quoted by Gautama Buddha " your work is to discover your work and then with all your heart to give yourself to it. That's the mark of a true professional."

True professional is always in search of work which boosts professional growth. A professional progress by all leaps and bounds. Subject based on Professional ethics and aptitude should be made part of curriculum.

Prime responsibility of a teacher is be true to self as he is builder of nation .So a sense of responsibility should be inculcated.

\section{Suggestions:}

- Certain refined criteria need to be established for admission in teacher training institutions.

- Mere percentage is not enough and guarantees to produce a quality teacher so Aptitude test should be taken before admission into Teacher Training institutions.

- Computer education should be made mandatory in Teacher Training at all levels .

- project works related to students problems should be introduced .

- Research should make place in teacher education institutions.

- Psychological tests must be made a part of syllabus and teacher trainees should get practical work.

- Workshops should be organized from time to time related with up-to-date educational activities.

- Though professionalism cannot be taught but it should be inculcated in teacher trainee 


\section{Conclusion}

In 21 st century teacher's role is not of a mere instructor but it is much more beyond it. He can't be restrained to certain areas or job .In true sense he is guide, philosopher, leader, creater, innovator, reflector and explorer .Now-a-days a learner has to be taken beyond limits of knowledge i.e free mind learning is to be acknowledged .Reflective thinking is to be developed mere understanding is not enough. All round development pertaining to cognitive, affective and psychomotor domain is to be worked. .Gone were the days where spare the rod and spoil the child concept was prevailing, now an alert mind can activate potential of learning through sychological ways and take out Desirable results .So the teacher educator and teacher training institutes have equal responsibility .NCTE and UGC has pivotal and vital place and role to improve degrading standards of education in training institutions. Guidelines have been established to maintain quality and standards but are they being executed as per need of the society?

Teacher trainees must get training for preparing Lesson Plans through power point presentation their practice should be commenced from Micro- Teaching and Macro-Teaching. Even final lesson plan should be delivered through PPT. Only a well planned and well versed teacher can do wonders in the classroom. He has not to do any magic by gilli-gilli, but has to reveal mastery of subject through various skills and improve his competence by RLO's.

\section{Books:}

\section{References:}

[1]. Essentials of Educational Psychology: J.C Aggarwal

[2]. A Textbook on child Development: Rajjamal P.Devdas ,N. Jaya

[3]. Modern Indian Education (Policies, Progess and Problems):C.P.S

Newspaper:

[4]. The Times of India New Teacher's Education Framework release.

\section{Websites:}

[5]. www.ncte-india.org

[6]. www.hindu.com 